\section{Brandeis $\mid$ urear}

brandeis.edu/j-caste
CASTE: A Global Journal on Social Exclusion

Vol. 2 No. I pp. I7-29

April 2021

ISSN 2639-4928

$10.26812 /$ caste.v2i1.308

\title{
Caste, The Origins of Our Discontents: A Historical Reflection on Two Cultures
}

\author{
Ibrahim K. Sundiata'
}

\begin{abstract}
In 2020 Isabel Wilkerson, Pulitzer prize-winning journalist, published Caste, The Origins of Our Discontents. An African American, she used the age-old hierarchy of India to hold up a light to the hierarchical 'racial' orders in the United States (Nazi Germany was included as a third case). Ever since the 1940s debate has raged over whether such a comparison is apt. In the United States, more than almost any other group, African Americans are inmarrying, residentially segregated, poor, linked to past forced labor, and stigmatized because of it. One argument put forward against comparison was that the Indian Dalits (the former 'untouchables') were inured to a system that was millennia old. However, slaves on Southern plantations were often described as being as humble and compliant as any Dalit. White slaveholders often thought of the India caste model. However, the very brevity of the full-fledged Cotton Kingdom (1820-1860) militated against the coalescence of a fully formed national caste consensus. The United States, unlike most places on the globe, had a constitutional armature in which, following the Civil War, former bondspeople could go from being property to voters de jure. In both societies the carapace of caste is now being cracked open, but this leaves open the question of whether we should reform caste or abolish it.
\end{abstract}

\section{Keywords}

caste, African American, Wilkerson, racial order, Dalit-slave comparison

\section{Introduction}

In 2020 Isabel Wilkerson, Pulitzer prize-winning journalist, published Caste, The Origins of Our Discontents. An African American, she uses the age-old hierarchy

\footnotetext{
'Emeritus Professor of History and African and African American Studies at Brandeis University Email: sundiata@brandeis.edu
}

(C) 202I Ibrahim K. Sundiata. This is an open access article distributed under the terms of the Creative Commons Attribution License, which permits unrestricted use, distribution, and reproduction in any medium, provided the original author(s) and source are credited. 
of India to hold up a light to the hierarchical 'racial' orders in the United States. She sees similarities, especially between India and the American South:

A caste system is an artificial construction, a fixed and embedded ranking of human value that sets the presumed supremacy of one group against the presumed inferiority of other groups on the basis of ancestry and often immutable traits, traits that would be neutral in the abstract but are ascribed life-and-death meaning in a hierarchy favoring the dominant caste whose forebears designed it. A caste system uses rigid, often arbitrary boundaries to keep the ranked groupings apart, distinct from one another and in their assigned places ...

We may mention "race", referring to people as black or white or Latino or Asian or indigenous, when what lies beneath each label is centuries of history and assigning of assumptions and values to physical features in a structure of human hierarchy. (Wilkerson, 2020, p. 382)

Wilkerson describes herself as a diagnostician rather than a clinician (Nazi Germany has been added almost as a grace note ignoring the millennium old Antisemitism, which only had legal respite in the years 1871-1933). Drawing on the American civil rights struggle and the political/spiritual example of caste opponent B. R. Ambedkar, she hopes to reframe our thinking. For Wilkerson, the word 'race' no longer adequately describes our reality. The journalist prefers replacing racial categories with the terms 'dominant caste', 'ruling majority', 'favored caste' or 'upper caste'. She also uses 'subordinate caste', 'lowest caste', 'bottom caste', 'historically stigmatized' caste. There are eight 'pillars of caste': endogamy, heritability, occupational hierarchy, dehumanization and stigma, cruelty and terror, and ideologies of inherent inferiority naturalized by religious doctrines. It is fear of annihilation through absorption by the 'Other' that is the axis of caste. As Wilkerson's book makes clear, in the United States, more than almost any other group, African Americans are inmarrying, residentially segregated, poor, linked to past forced labor, and stigmatized because of it.

In both America and India hierarchy has been challenged by men of faith. Martin Luther King, the Nobel-winning 'drum-major' of the Civil Rights Movement, first studied Mahatma Gandhi as a seminary student in 1949; 'Christ showed us the way, and Gandhi in India showed it could work.' In 1959, a decade after seminary, he visited India, announcing that, 'To other countries I may go as a tourist, but to India I come as a pilgrim.' King's great Indian counterpart was not so roseate. Dalit ('Untouchable') jurist and legislator Bhimrao Ramji Ambedkar (1891-1956) stood resolute against any sanctimonious religious defense of caste, which he denounced as a system of 'graded inequality' structured around an 'ascending scale of reverence and a descending scale of contempt' (Rao, 2020).

Wilkerson has been faulted for comparing apples and oranges. Was Indian society so frozen in time as to defy comparison? Anthropologist Arjun Appadurai (2020), critiquing her, remarks:

'either India has no underlying social programme, grammar and theory, and its social world is simply caste all the way up and down (something I doubt), 
or Wilkerson's dramatic unearthing of caste under the surface of race in the US is just a literary device to tell a familiar American story in an unfamiliar way and is not based on a genuine similarity.'

A riposte is that caste is imbedded within Vedic religion which is a 'social programme, grammar and theory.' Social scientist Rajesh Sampath (2020, p. 22) warns against mystification of a 'supersensory ancient past.' Some 'may speculate ... regarding the distant hallucinogenic Vedic origins and propositions about cosmic cycles of time, creation, and destruction ...' However, what should concern the investigator is that 'divine law codes tried to engineer, in the name of Hinduism's fundamental truths, a social order that is highly stratified, unequal, and supremely unfair.'

What was the caste order? The hoary millennia-old Laws of Manu, overlayed with many accretions, decreed four inmarrying groups. There are four castes, known as varnas, namely Brahmins or the original priests and scribes; Kshatriyas, the warriors, and kings; Vaishyas the merchants and business class; Shudras or the agriculturalists. Each caste has innumerable subcastes, or jatis, and, over generations, some jatis have risen while others have declined. The three higher varnas are often referred to as 'caste Hindus' (upper caste Hindus) or as 'twice born', since the men of these castes enter an initiation ceremony (the second birth) and are allowed to wear a sacred thread. Together, the upper castes constitute 17-18 percent of the Indian population. The Shudras are the largest caste, making up nearly half of the population. ${ }^{1}$ Below the Shudras are the Dalits, formerly the 'untouchables'. For centuries they have done the society's dirty work - they were forbidden to enter temples, to draw water, to walk down the same roads, wear shoes in higher-caste neighborhoods. They are roughly 16 percent of the population.

In 1941 a major comparison between India and the American South appeared in Black sociologist Allison Davis and his colleagues' groundbreaking study, Deep South: A Social Anthropological Study of Caste and Class (1941). ${ }^{2}$ The analysis was bleak and there was pushback. Jamaican-born anthropologist Oliver Cromwell Cox (1948, p. 42) asserted that 'So far as we have been able to determine, developed castes exist in no other part of the world.' To Cox, in India hierarchy had been frozen in place for millennia; 'caste barriers in the caste system are never challenged.' He was wrong. There are various castes in the world and not all of them need the armature of polymorphous Hindu polytheism. (The Cagot of the Basque region and the Burakumin of Japan are usually viewed as a caste without any resort to reference to the body of the Hindu-god Brahma). ${ }^{3}$

In the United States the 'races' were (and often still are) viewed as primeval and incapable of intermixing, locked in a kind of pseudoscientific polygenetic immiscibility (these 'races', originally conceived of as being of different species). In the midst of the Civil War racists came up with a special word, miscegenation, to describe interracial coupling. In 1930 the Federal Census said that any human being with one Black ancestor can never be 'White'. Whiteness can be 'polluted' by Blackness, but not

\footnotetext{
${ }^{1}$ Some are very poor but have not been treated as polluted. The blanket term 'Other Backward Classes' (OBCs) is supposed to capture these groups that have been defined in the constitution as 'socially and educationally backward classes.'

${ }^{2}$ Davis headed a research team that included his wife and a Swedish couple, the Gardners.

${ }^{3}$ For centuries, through the modern times, the majority regarded Cagots who lived primarily in the Basque region of France and Spain as an inferior untouchable caste. The socially isolated Cagots were "The Last Untouchable in Europe", The Independent (London), July 28, 2008.
} 
the reverse. In many places by law interracial marriage was a sex crime on the level with homosexuality or bestiality until 1967 (We should remember that the United States' definition of who was a 'Negro' was far more stringent than Nazi Germany's definition of who was a Jew).

Ambedkar believed that what distinguished the Blacks in the United States and Dalits in India was the acceptance of innate inferiority. He believed that 'A deprivation of a man's freedom by an open and direct way is a preferable form of enslavement. It makes the slave conscious of his enslavement and to become conscious of slavery is the first and most important step in the battle for freedom.' However, 'if a man is deprived of his liberty indirectly, he has no consciousness of his enslavement. Untouchability is an indirect form of slavery. ${ }^{4}$ In this Ambedkar may have underestimated both the brief time period and the lingering stigma of American slavery. Here we need to remember Antonio Gramsci's 'hegemonic ideology'. Both the subaltern groups and those that dominate them have to participate, at some level, in the same ideological space in which both accept the basic explanations of the sociopolitical order (Gramsci, 2011). Many of the enslaved in Dixie called themselves 'niggers' because they had no other term. Some internalized the racism and paternalism of the dominant group. By the 1840s, slave owners argued that the Federal census should not take down slave names, as they only marked a piece of property and might be changed at the whim of the owner. States passed laws prohibiting slaves from reading and denying abolitionists the use of the mails. To think that antebellum slaves born on large plantations in the Deepest South, far from the nearest town, were any freer from hierarchical thinking than Dalits is a risky surmise. What critics have failed to notice is the great variance in the two systems' longevity. The full-blown Cotton Kingdom of the Deep South was of relatively short duration (1820-1860). Denouncing Jeffersonian egalitarianism as a delusion, in the 1840s John C. Calhoun of South Carolina rhapsodized about creating a completely closed new system: '[A]bove all, we have a cheap and efficient body of laborers ... for whose labor we have paid in advance ... With these advantages we may bid defiance to Hindoo or Egyptian labor ...' ${ }^{5}$ The cataclysm of the Civil War did indeed bring legal slavery down. But Reconstruction left the socioeconomic structures of caste intact, while attempting to square them with 'equality before the law'. It was this rupture that made caste relations in the United States so violent and unstable. In 1831 Alexis de Tocqueville had predicted: 'The negroes may long remain slaves without complaining; but if they are once raised to the level of free men, they will revolt at being deprived of all their civil rights ... ${ }^{6}$ During Reconstruction, Black men went from being chattel to voting citizens in the space of little over a decade (It is important to realize that all 'White Men' did not get suffrage in Britain until 1918).

${ }^{4}$ Ambedkar Writings and Speeches, Vol. p. 65, cited in S. D. Kapoor. (2003). B. R. Ambedkar, W. E. B. DuBois and the process of liberation. Economic and Political Weekly, 38(51/52): 5345, Retrieved April 15, 2021, http://www.jstor.org/stable/4414430

${ }^{5}$ Matthew Karp, This Vast Southern Empire, Slaveholders at the Helm of American Foreign Policy (Cambridge, MA: Harvard University Press, 2016), p. 30, citing Green, "The United States and England",13; John C. Calhoun, speech in Senate, March 16, 1842, PJCC, 16:192-94.

${ }^{6}$ Alexis de Tocqueville, Democracy in America, chapter XVIII: Future Conditions of Three Races - Part V (1831) https://www.marxists.org/reference/archive/de-tocqueville/democracyamerica/ch18.htm

${ }^{7}$ Four-thousand eighty-five African Americans were lynched between 1877 and 1950. In 1921, in what can only be termed an American 'pogrom' over one-hundred African Americans were 
There were revolts throughout slavery in the Americas, but compared to other New World slaveries, United States' revolts were minor. The 1863 Emancipation Proclamation warned the enslaved not to revolt. They did not. Almost thirty years later, Booker T. Washington, the leading Black spokesman of his time, reminded Southern Whites how four million slaves had remained loyal to the Confederate old master and mistress. In the 1950s, Stanley Elkins (1959) came up with the idea of the plantation as an analogue of the Nazi camps and producing the 'Sambo,' the stereotypical compliant Black. And we must remember that the 1954 Federal decision to racially desegregate public schools was greatly influenced by detailed studies of the psychological scars of segregation, especially the argument that Black students had internalized racism. ${ }^{8}$ Ambedkar's comment does point to a central weak point in the American version of caste hierarchy. It existed within a purported democracy (described by George Fredrickson (1982) and others as a 'Herrenvolk ["Master Race"] Democracy'.

A few White Southerners looked to India as an inspiration and a warning. One of the foremost American segregationist, Theodore Bilbo (1947, p. 14) of Mississippi, looked to caste in India both as a model and a warning: 'When the Hindoos, Aryans of the migratory Caucasian race, arrived in India, they found themselves surrounded by a mass of yellow-black-white mongrels ... As the blood became corrupted, the culture and civilization became stagnant and decayed.' The segregationist was regurgitating stale imperialist anthropology. And this anthropology itself was often 'a fantastic back-projection of systems of racial segregation in the American South and in South Africa onto early Indian history ...' On the subcontinent European experts posited color stratification as the basis for caste: 'white' for Brahmins, 'red' for Kshatriyas, 'yellow' for Vaisyas and 'black' for Shudras (Klass, 1980).

Wilkerson mentions 'ideologies of inherent inferiority naturalized by religious doctrines.' The South developed its own. The 'Curse of Ham', the assertion that Noah cursed his son Ham's son Canaan slowly developed in the ancient world and then took off in America. When Jefferson Davis, president of the Confederacy, said that Africans were 'stamped from the beginning', he was arguing that Blacks had a multigenerational 'bad karma' of scriptural origin. ${ }^{9}$ Standing behind this racial exegesis was a perdurable ideological substrate. As part of the Western inheritance we have Manicheanism, a Middle-Eastern religion that once stretched from western China into the bowels of the Roman Empire. Mani the Prophet, who lived in Iran two centuries after Christ, proclaimed a radical dualism between good (light) and evil (dark). All the worlds revolved around these two principles, the first existing in the spirit, the second enslaved in the flesh. The two are locked in eternal combat. Both blacks and whites are chained together in this dualism. The great Nat Turner Rebellion in Virginia in 1831 began with the preacher seeing a vision of White Spirits and Black Spirits battling in a bloody sky. When award-winning Afro-Pessimist Frank Wilderson (2020, p. 41) says that 'Human life is dependent on Black death for its existence and for its coherence'

murdered in Tulsa, Oklahoma as the result of business competition. The Great Migration of Blacks to the North was marked by repeated clashes.

${ }^{8}$ NAACP Legal Defense Fund, https://www.naacpldf.org/ldf-celebrates-60th-anniversarybrown-v-board-education/significance-doll-test/

${ }^{9}$ Genesis 9, 20-7. 
he is only the latest iteration of the heresy that underpins our racial order. ${ }^{10}$ He presents Manicheanism stripped naked of theology and decked out as ontology.

A colleague of mine at another institution argues that the idea of ritual pollution separates the position of the Dalits and African Americans. The image of the nurturing 'Mammy' - factotum and surrogate mother - was a staple of plantation lore in the United States. But proximity does not imply a lack of social distance or even degradation. Mammies who 'back-talked' could be whipped or sold. The nurturance they gave to White infants might even be seen as form of dehumanizing them. This idea would be reinforced by a scene from Nobel-winner Toni Morrison's Beloved. A fleeing slave woman is surrounded by a gang of White men who brutally rape her and then take the lactating woman's milk. Yes, the animalistic sex meant physical proximity, but it only served to emphasize the distance between man and beast. In present-day India, caste men often rape Dalit women during communal violence. 'Untouchability' does not signify any absolute ban on physical contact, only contact which might imply any degree of mutuality.

Touch in the United States was frequently seen as polluting. When Booker T. Washington took tea in the White House with Theodore Roosevelt, Southern newspapers screamed that no White woman could ever dine there again. We must also remember that Southern mores and sometimes laws prohibited interracial hand shaking or playing checkers. Swimming pools and beaches were places of special danger. In 1919 a major race riot erupted when a Black youth drifted into 'white' water in Chicago's Lake Michigan. Wilkerson (2020) tells a story dating years later when a hotel drained its pool rather than let a Black body bathe.

Although separated by thousands of miles and centuries of culture, some African Americans and the Indian oppressed have reached out to each other. Starting in the nineteenth century, lower-caste Indians looked to the United States' inspiration in fighting inequality. Jyotirao Phule, an anti-Brahmin activist dedicated his 1873 book, Ghulamgiri or Slavery, to American abolitionists. In 1928 W. E. B. DuBois wrote a political novel Dark Princess that focused on a romance between a globe-trotting African American hero and an Indian princess. DuBois, still in his elitist phase, has his hero meet Princess Kautilya of Bwodpur, daughter of a maharajah. She bears his child, the promise of a new brown world a-dawning. ${ }^{11}$ The next year the African American scholar wrote to Gandhi to solicit his support. ${ }^{12}$ Gandhi replied that he saw no disgrace in being a slave; the disgrace lay with the slaveowner. ${ }^{13}$

\footnotetext{
${ }^{10}$ Frank Wilderson III, Afropessimism (New York: Liveright, 2020), p. 41. Also see interview with C. S. Soong, Blacks and the Master/Slave Relation in Afro-Pessimism, An Introduction, (Minneapolis, MN; Racked \& Dispatched, 2017, racked \& dispatched.noglogs.org//:

${ }^{11}$ Some have speculated that the Indian princess may have been based on the Indian independence activist Bhikaji Cama.

${ }^{12}$ W. E. B. DuBois to Mahatma Gandhi, February 19, 1929. https://credo.library.umass.edu/ view/full/mums312-b181-i613. Also see Anindya Sekhar Purakayastha, W. E. B. DuBois, B. R. Ambedkar and the History of Afro-Dalit Solidarity, Sanglap: Journal of Literary and Cultural Inquiry, January 2020. https://paperity.org/p/229421827/w-e-b-du-bois-b-r-ambedkarand-the-history-of-afro-dalit-solidarity

${ }^{13}$ Mahatma Gandhi to W. E. B. DuBois, May 1, 1929. https://minervasperch. wordpress.com $/ 2018 / 12 / 15 / \mathrm{mahatma-gandhi-message-to-the-american-negro-}$ 1929/\#: :text=Mahatma\%20Gandhi\%2C\%20Message \%20to\%20The\%20American\%20 Negro\%2C\%201929,being\%20slaves.\%20There\%20is\%20dishonour\%20in\%20being\%20 slave-owners.
} 
Seven years after the Gandhi-DuBois correspondence, long-time president of Morehouse College in Atlanta, Benjamin Mays, visited India, observing:

While at Mysore I was invited by the headmaster of an "untouchable" school in a neighboring village to speak to his students. I asked him why, since there were thirteen U.S. delegates, he had chosen me. He replied that he wanted a Negro; and when I told him that Channing Tobias was also a Negro, he answered that Tobias was too fair of complexion to do what he wanted done. "I want you." I accepted his invitation and, on leaving Mysore, went to his school where I dined with his untouchable students. After dinner, I was introduced as an untouchable who had achieved distinction. The headmaster told them that I had suffered at the hands of white men in the United States every indignity that they suffered from the various castes in India and that I was proof that they, too, could be "somebody worthwhile" despite the stigma of being members of a depressed class. (Darity, 2014; Pandey, 2010)

Mays observed that in his homeland: 'I was not permitted to sleep or eat in white hotels and restaurants and was barred from worship in white churches. I had been slapped almost blind because I was black and had been driven out of a Pullman car with pistols at my back. I - just as they [Dalits] - through the mere accident of birth was indeed an untouchable' (Ibid). The following year, sponsored by the Indian Student Christian Movement, Black theologian Howard Thurman, a colleague of Mays, led a four-member delegation to India and the surrounding countries. Towards the end of the tour the group met with Gandhi, who pronounced, 'It may be through the Negroes that the unadulterated message of nonviolence will be delivered to the world.' Shortly after Gandhi's death, Ambedkar corresponded with DuBois and noted that there was 'so much similarity between the position of the Untouchable in India and the position of Negros in America that the study of the latter is not only natural but necessary.' He wrote to the Black scholar expressing great interest in DuBois' plan to place the condition of the African American people before the United Nations. ${ }^{14}$

In 1959, Martin Luther King, mentee of both Mays and Thurman, visited India. He crisscrossed the country. During his time in Delhi, the preacher discussed his perspectives on nonviolence with then Indian Prime Minister Pandit Jawaharlal Nehru. In Madras (Chennai), he met Swami Vishwananda, an ardent opponent of untouchability. In Gandhigram, King gave a devotional message at an interfaith gathering and went on to visit Dalit villages. In Mumbai, King got to stay at Mani Bhaven, Gandhi's residence. The visitor spoke to a public meeting and challenged the assumption that human beings must be satisfied with their lot. At the beginning of March, King and his wife traveled to Ahmedabad, where they visited the Sabarmati Ashram where Gandhi had begun his 1930 Salt March to the sea. On March 9, King made a farewell address in which he reflected:

${ }^{14}$ The Papers of W. E. B. DuBois (Sanford, N.C.: Microfilming Corporation of America, 1980), reel 5ii118, frames 00467-00468. There is no other correspondence between the two figures in the DuBois papers. See also Luis Cabrera, Ambedkar and DuBois on Pursuing Rights Protections Globally, 21st Century Global Dynamics, January 4, 2018, 11(1) https:// www.21global.ucsb.edu/global-e/january-2018/ambedkar-and-du-bois-pursuing-rightsprotections-globally 
'Since being in India, I am more convinced than ever before that the method of nonviolent resistance is the most potent weapon available to oppressed people in their struggle for justice and human dignity. In a real sense, Mahatma Gandhi embodied in his life certain universal principles that are inherent in the moral structure of the universe, and these principles are as inescapable as the law of gravitation. ${ }^{\prime 15}$

The pilgrimages of Black leaders to India were a marvelous conjuncture. Satyagraha was a discipline and an ideology that appealed its sophistication and simplicity. It was the weapon of the weak and in India it proved successful in mobilization for independence. For African Americans in the Manichean struggle against the Color Line it promised solidarity with India's millions. Much has already been written about this (Hill, 2007). But what about the historical context? At times, solidarity could be misunderstood and simplified. For instance, DuBois was much taken with the idea of non-white elites and failed to grasp the full meaning of the plight of the Dalits (Carson et al., 1992). 'Untouchables' qua 'Untouchables' were of little concern to him and he at one-time embraced Japanese imperialism as a counterweight to European imperialism. (In this he prefigured Subash Chandra Bose). ${ }^{16}$

Today, both India and the United States struggle with gaping inequities in power and wealth. And their solutions bear some resemblance, as do their failures. Both suffer from maldistribution of wealth. A January 2020 study by rights group Oxfam India suggests that India's richest one percent hold more than four times the wealth held by 953 million people who make up for the bottom 70 percent of the country's population. According to the study, India's top 10 percent holds over 74 percent of the total national wealth (Das, 2020). And there is another reality. According to one expert, in rural India in 2010, Dalits 'still live in secluded quarters, do the dirtiest work, and are not allowed to use the village well and other common facilities' (Klostermaier, 2007). According to the Socio-Economic and Caste Census 2011, 73 percent of Dalit households are the most deprived among rural households. Forty-five percent of Dalit households are landless and earn a living by manual day labor (Indian Express, 2015). At one point, Manmohan Singh, when Prime Minister of India, drew a parallel between apartheid and untouchability (HRW, 2002).

Ambedkar's movement demanded quota (reservation) as a basic pillar of the postindependence political order. ${ }^{17}$ Around 22 percent of all government jobs, places in educational institutions with government funding, and electoral districts at all levels

\footnotetext{
${ }^{15}$ Stanford University, The Martin Luther King, Jr. Research and Education Institute, King Papers, February 3, 195950 March 18, 1959, p. 5:136 https://kinginstitute.stanford.edu/ encyclopedia/india-trip

${ }^{16}$ In the early1930s DuBois misread the Poona Accord as something that had been stuffed down the Indian National Congress' throat rather than an agreement between Gandhi and Ambedkar. In the mid-1930s DuBois praised Japanese imperialism in East Asia as a brutal but necessary step in resisting white imperialism. Reginald Kearney, The Pro-Japanese Utterances of W. E. B. DuBois, Contributions in Black Studies: Vol. 13, 1995, Art 7. Available at: https://scholarworks. umass.edu/cibs/vol13/iss1/7.

${ }^{17}$ In 1932, fifteen years before independence, the British administration recommended separate electorates to select leaders for Dalits in the Communal Award. This was favored by Ambedkar but when Mahatma Gandhi opposed the proposal, it resulted in the Poona Pact. That in turn influenced the Government of India Act, 1935, which introduced the reservation of seats for the depressed classes, now renamed as Scheduled Castes.
} 
are reserved for the Scheduled Castes and tribal persons. At the local level, this may have some impact in the distribution of local services. At present there are major Dalit political parties as well as key Dalit politicians. Some of the elected Dalits are from mainstream parties and follow platforms not specifically addressed to the social group. As there are non-Dalit votes in each constituency, candidates must sometimes appeal to issues of importance to more than one caste.

During the initial years of independence, Dalit voters were largely loyal to the Congress Party. ${ }^{18}$ Then, in 2014, the Hindu nationalist Bhartiya Janata Party (BJP) achieved national power. Cleverly, the BJP began courting former 'Untouchables' by exploiting their economic divisions. Hindu nationalists, still deeply wedded to caste, promised them economic benefits. In 2019, a third of Dalits voted for BJP in the national elections. Prime Minister Narendra Modi, returned to power (Khilnani, 2020). ${ }^{19}$ Currently imprisoned Dalit intellectual and activist Anand Teltumbde believes that 'the debacle of the Dalit movement' today lies in its inability to recognize how class intersects with caste' (Ibid). Indeed, reservation has benefitted some sections of the community, leaving others behind. There are Dalit companies with Dalit millionaires. Two presidents of India, K. R. Narayanan, and Ram Nath Kovind have been Dalits. The privileged group among the formerly completely excluded people has come to be known as 'the creamy layer'.

We now have a Dalit literary boom and symbolic celebrations like Phule Jayanti along with the Bhim Army and Ambedkarite-Marxist alliances. ${ }^{20}$ In addition, there is now a National Campaign on Dalit Human Rights (NCDHR). Rising expectations bring in their train heightened tensions. Mob attacks are not infrequent, and, at times, Dalits are ritually humiliated. A disproportionate number of rapes are committed against their women. Several years ago, the Dalit women's movement reached out to Black Lives Matter for advice on organizing. Dalits even had their own self-defense organization, the Dalit Panthers, founded in 1972 in Maharashtra. In 1989, Parliament passed the Scheduled Castes and Scheduled Tribes Prevention of Atrocities Act. Twenty-six years later it renewed and strengthened it. The United States has its own forms of 'reservation'. Well before 'affirmative action', the Federal imprimatur for civil rights came during the Truman administration. The armed services were racially integrated in 1948 and the Democratic Party platform embraced civil rights. Six years later the Supreme Court overturned racial segregation in public schools. The Civil Rights Act of 1964 banned racial discrimination in Federals assisted programs and

\footnotetext{
${ }^{18}$ In some states, Dalits voted for their own caste-based regional parties.

${ }^{19}$ Sunil Khilnani, 'Isabel Wilkerson's World-Historical Theory of Race and Caste', The New Yorker, August 7, 2020. Suraj Yengde, a Dalit scholar at Harvard's Kennedy School of Government, sees possible benefits in his caste's lack of unity. As parties compete for their votes, Dalits may have a greater range of less corrupt candidates to choose from.

${ }^{20}$ We now have a wide literature. Vijay Prashad's essay Afro-Dalits of the earth unite (2000) and subsequently a series of significant works such as The Dalit Panthers: race, caste, and black power in India in Nico Slate's Black power beyond borders: the global dimensions of the black power movement (2012); Gyanendra Pandey's A history of prejudice: race, caste and difference in India and the United States (2013); Purbi Mehta's doctoral work Recasting caste: histories of dalit transnationalism and the internationalization of caste discrimination (2013); Manan Desai's Caste in black and white: dalit identity and the translation of African American literature (2015); Bacchetta, Maira \& Winant's Global raciality: empire, post-coloniality, decoloniality (2019); Afro-Asian Networks Research Collective's 'Manifesto: networks of decolonization in Asia and Africa' in Radical History Review, 131(2018); Nico Slate's Lord Cornwallis is dead: the struggle for democracy in the United States and India (2019).
} 
employment. The administration of Lyndon B. Johnson followed up with a series of executive orders. Under Executive Order 11246, issued in 1965, federal contractors who failed to take affirmative action to end discrimination risked exclusion from competition for future contracts. To oversee implementation, the Federal government established the Office of Federal Contract Compliance Programs (OFCCP) and the Equal Employment Opportunity Commission (EEOC). By the end of the twentieth century, quotas for African Americans had been disallowed, but race-conscious policies were encouraged in many cases.

As more inner cities turned Black, the populace fought back against indignities visited upon them. The Black Panther Party for Self-Defense was founded in California in 1966 to confront the situation. Another grim testament to racial violence were the violent 1968 outbursts that marked the assassination of King, the American apostle of Gandhian nonviolence. Police brutality has continued to be a trigger (Los Angeles 1991; Ferguson, Missouri 2014). In 2020 in Minneapolis, a White police officer knelt on the throat of a Black suspect, George Floyd, crushing the bound man's neck while being filmed. Many in the shocked public united behind the banner of 'Black Lives Matter' and demonstrations involving hundreds roiled the country for months.

Behind this violence lies a significant and much discussed Black/White wealth gap. In 2019, according to the Federal Reserve, the typical White family has eight times the wealth of the typical Black family (Bhutta et al., 2020). Black families' median and mean wealth is less than 15 percent of that of White families. Blacks live in segregated communities and still go to de facto segregated schools. Black women are four times likely to die in childbirth as White women. One signal difference between India and the United States is the issue of incarceration. While Dalits (including both Scheduled Castes and Scheduled Tribes) constitute 25 percent of the Indian population, they account for 33.2 percent of prisoners (Arunachalam, 2014). About 24.5 percent of inmates condemned to death are from Scheduled Castes and Scheduled Tribes, which is proportionate to their population. Remarkably, the United States has a prison population higher than much more populous India. In 2018, African Americans were 33 percent of the prison population; nearly triple their 12 percent of the total population (Gramlich, 2020).

These are hard, cold facts. Isabel Wilkerson has been criticized for being overly romantic. She speaks of empathy: 'Radical empathy ... means putting in the work to educate oneself and to listen with a humble heart to understand another's experience from their perspective, not as we imagine we would feel' (Wilkerson, 2020, p. 386). Indeed, 'each time a person reaches across caste and makes a connection, it helps break the back of caste.' Poetically, she muses that 'Multiplied by millions in a given day, it becomes the flap of a butterfly wing that shifts the air and builds to a hurricane across an ocean.' One Indian critic, Sunil Khilnani (2020) remarks:

This resort to moral psychology - a self-oriented Gandhian move of the kind that infuriated Ambedkar - seems a retreat from her larger argument that white supremacy should be seen as systemic, not personal. Perhaps, boxed in by her caste model, she is seeking hope by reaching outside it. But, if the caste model can feel unnuanced and overly deterministic, the turn toward empathy can feel detached from history in another way. After all, were every white person in America to wake up tomorrow cured of what Wilkerson terms the "disease" of caste, the change of heart alone would not redress the deprivation 
of human, financial, and social capital to which Blacks have been subjected for centuries. Talk of "structural racism" is meant to highlight this difficult truth; Wilkerson's understanding of caste, by emphasizing norms of respect over the promptings of distributive justice, can sometimes obscure it.

This is a signal misreading of Ambedkar. Indeed, his leaving Hinduism behind was based on his strong belief that his people needed a kind of racial moral realignment. It was not just enough to change the legal and legislative system. Nor was it enough to call for redistributive justice within the ongoing carapace of caste. The Indian leader believed that a purely materialist approach to the problem of his people would be futile and turned to Buddhism, a non-caste-riven faith. There is no American demand for the 'abolition of race' equal to Ambedkar's call for 'the annihilation of caste'. The Dalit leader might debate intercaste dinning and intercaste marriage with Gandhi; one can imagine Martin Luther King urging integrated restaurants, but any discussion of sexual contact was deliberately avoided. Americans have never really moved beyond the Supreme Court's 1896 'separate but equal' ruling. In 1971, Carl Degler (1971) wrote that forms of segregation, for instance separate universities, had benefitted Blacks. Civil rights and civic participation would be the end of the American project. His book, Neither Black nor White, won three major national awards, including the Pulitzer, and became one of the bases of a post-Civil Rights liberal consensus. Now a number of African American scholars, among them Ibram Kendi (2017), argue that assimilationism is racism, on par with segregationism. The 'separate but equal' once promised but never attained must now be loudly demanded from the White majority.

We must avoid the tendency to nihilism. Action without reflection will only result in 'more of the same'. The United States can learn much from Ambedkar's example in India; caste is not simply overthrown by new and better laws that promise civic access. It is not even done away with by policies that promise economic amelioration. If groups are viewed as different in their essence, no amount of social engineering will bridge the empathy gap. Belief in innate and immutable group characteristics, however packaged in the language of 'diversity', carries within itself the danger of perpetuating the specious notion of 'separate but equal'.

Barack Obama's election in 2008 was celebrated by many as the end of 'caste' in America. Ignoring caste, religion, region, and color, one Indian riposted:

Obama's 2008 election was hailed by many as the birth of a "post-racial" America. As Indians, we're rather amused by all the excitement in the US and the rest of the world at the election of a minority to the office of the President. In India, we had a woman Prime Minister in the '70s, a Sikh President in the '80s, a lower-caste (equivalent to Negro in the US) President in the early '90s, a Muslim President in the late '90s, and right now a woman President, a Sikh Prime Minister, and a Christian leader of the governing party. In addition, we have had a Jewish Chief of Army Staff in the '80s, and now two Christian defense secretaries (the equivalent of this last would be a Hindu defense secretary in the US). In India, we simply take this for granted because we have been a multi-cultural, multi-ethnic, multi-religious, and multi-lingual nation for so long ... we had our Obama moment 30 years ago. Indeed, if Obama had been born in India, he would have been elected in the ' $60 \mathrm{~s}^{21}$

${ }^{21}$ Radio Free Europe/Radio Liberty www.rferl.org/content/world_Congratulates. Obama_OnVictory/338474.html. Posted By: jimgreen@11/21/2008 11:58:49 AM 
Obama's rise, like the later rise of half-Indian Brahmin Vice-President Kamala Harris, perhaps more aptly represents the arrival of the United States' own 'creamy layer'. As in India, there are caveats. Wilkerson cautions us that caste can change so that things remain the same: 'Without an enlightened recognition of the price we all pay for a caste system, the hierarchy will likely shape-shift as it has in the past to ensure that the structure remains intact.' Furthermore, the definition of whiteness could well expand. The result would be to increase the ranks of the dominant caste ... a reconstituted caste system could divide those at the bottom from those in the middle, pick off those closest to white and thus isolate the darkest Americans even further, lock them ever more tightly to the bottom rung' (Wilkerson, 2020, p. 349). If we assume that our hoary pigmentocracy must continue for another four hundred years with new names and new players, we will indeed, drown in our discontents - the bitter fruits of our failure to confront our own caste system. Radical empathy maybe the precondition for coherent social action.

\section{References}

Appadurai, Arjun. (2020, September 12). Comparing race to caste is an interesting idea, but there are crucial differences between both. The Wire, Retrieved on November 25, 2020, https://thewire.in/books/book-review-isabel-wilkerson-caste-racism-america

Arunachalam, Pon Vasanth. (2014, November 3). Skew in Dalit jail inmate ratio: NCRB. The New Indian Express.

Bhutta, Neil., Andrew, C., Chang, Lisa., Pettling J., Joanne, W., Hsu, and Hewitt, Julia. (2020, September 28). Disparities in wealth by race and ethnicity. 2019 Survey of Consumer Finance, Retrieved on November 25, 2020, https://www.federalreserve.gov/ econres/notes/ feds-notes/disparities-in-wealth-by-race-and-ethnicity-in-the-2019-survey-of-consumerfinances-20200928.htm

Bilbo, Theodore. (1947). Take your choice: separation or mongrelization. Popularville, MS: Dream House Publishing.

Bilwakesh, Nikhil. (2011). Their faces were like so many of the same sort at home. American Periodicals: A Journal of History Criticism and Bibliography, 21(1), 1-23.

Cabrera, Luis. (2018). Ambedkar and DuBois on pursuing rights protections globally. 21st Century Global Dynamics, 11(1), Retrieved on November 25, 2020 https:/www.21global. ucsb.edu/global-e/january-2018/ambedkar-and-du-bois-pursuing-rights-protectionsglobally

Carson, Clayborne., Holloran, Peter., Luker, Ralph E., and Russell, Penny A. (Eds.) (1992). Martin Luther Papers 5:136. In The papers of Martin Luther King, Jr. Berkeley: University of California Press.

Cox, Oliver Cromwell. (1948). Caste, class and race: a study in social dynamics. New York: Monthly Review Press, 19480.

Darity, William. (2014). Race, caste, class and subalternity. The Journal of Asian Studies, 73(4), $1085-1090$.

Das, Koustav. (2020). Explained: How a raging pandemic is widening India's wealth gap. India Today, Retrieved on November 25, 2020, https:/www.indiatoday.in/business/ story/explained-how-a-raging-pandemic-is-widening-india-s-wealth-gap-1722726-20200917\#: :text=A\%20January\%202020\%20study\%20by,cent $\% 20$ of $\% 20$ the $\% 20$ country's\%20population. 
Davis, Allison., Burleigh, B., and Mary R. Gardner. (1941). Deep South: a social anthropological study of caste and class. Chicago: University of Chicago Press.

Degler, Carl. (1986). Neither white nor black, slavery and race relations in Brazil and the United States. Madison, WI: University of Wisconsin Press [first published 1971].

Elkins, Stanley M. (1959). Slavery: a problem in American institutional life. Chicago: University of Chicago Press.

Fredrickson, George. (1982). White supremacy: a comparative study of America and South African history. New York: Oxford University Press.

Gramlich, John. (2020). What the data says (and doesn't say) about crime in the United States. Factanks, Pew Research, Retrieved on November 25, 2020, https://www.pewresearch.org/ fact-tank/2020/11/20/facts-about-crime-in-the-u-s/

Gramsci, Antonio. (2011). The prison notebooks volumes 1, 2 \& 3 (trans. Joseph A. Buttigieg). New York: Columbia University Press.

Hill, J. B. (2007). The power of nonviolence: Mohandas K. Gandhi's influence on King and Tutu. In J. B. Hill (Ed.), The Theology of Martin Luther King, Jr. and Desmond Mpilo Tutu (pp. 129-151). New York: Palgrave Macmillan.

Human Rights Watch (HRW). (2002, May 27). India's 'hidden apartheid' of discrimination against Dalits, Human Rights Watch.

Indian Express. (2015, July 6). Landlessness is higher among Dalits, but more adivasis (tribal people) are 'deprived'. The Indian Express.

Kendi, Ibram X. (2017). Stamped from the beginning, the definitive history of racist ideas in America. New York: Bold Type Books.

Khilnani, Sunil. (2020, August 7). Isabel Wilkerson's world-historical theory of race and caste. The New Yorker.

Klass, M. (1980). Caste: the emergence of the south Asian social system. Philadelphia: Institute for the Study of Human Issues.

Klostermaier, Klaus. (2007). A survey of Hinduism. London: One World Publications.

Pandey, Gyanendra. (Ed.) (2010). Review essay of Subaltern citizens and their histories: investigations from India and the USA. New York: Routledge.

-(2011). Review essay of Subalternity and difference: investigations from the North and South. New York: Routledge.

Purakayastha, Anindya Sekhar. (2020). W. E. B. DuBois, B. R. Ambedkar and the history of Afro-Dalit solidarity. Sanglap: Journal of Literary and Cultural Inquiry, Retrieved on November 25, 2020, https://paperity.org/p/229421827/w-e-b-du-bois-b-r-ambedkar-andthe-history-of-afro-dalit-solidarity

Rao, Anupama. (2020, September 1). The work of analogy: on Isabel Wilkerson's caste: the origins of our discontents, Los Angeles Review of Books.

Sampath, Rajesh. (2020). A commentary on Ambedkar's posthumously published 'Philosophy of Hinduism'. CASTE: A Global Journal on Social Inclusion, 1(1), Retrieved from https:// journals.library.brandeis.edu/index.php/caste/article/view/141/13

Wilderson III, Frank. (2020). Afropessimism, New York: Liveright.

Wilkerson, Isabel. (2020). Caste, the origins of our discontents, New York: Random House. 